\title{
USING SocIAL MEdiA AS A TOOL FOR PROMOTING FESTIVAL TOURISM
}

\author{
Krittanai Ngernyuang ${ }^{1}$ and Pei-Ying $\mathrm{Wu}^{2}$ \\ ${ }^{1}$ Department of Tourism and Leisure, Chung Hua University, Hsinchu, Taiwan \\ ${ }^{2}$ Department of Tourism and MICE, Chung Hua University, Hsinchu, Taiwan
}

\begin{abstract}
The impact of social media on Tourism has been one of the main topics in tourism research. Many studies discuss and analyze the impact of social media on Tourism. However, less research studied on the impact of social media on specific, like festivals tourism. Festival make people united and the experiences of those participating in festivals can have a significant influence on others and social media provides the perfect channel for sharing their experiences.

This research focused on social media factors that influenced visitors in the festival tourism. The study was designed to explored how social media factors impact to festival tourism. The structured interview was conducted to confirm social media factors from secondary data. The results show that social media better use as a search engine tools. For future research it is suggested to conduct quantitative survey to confirm these social media factors which analyzed by this study.
\end{abstract}

\section{KEYWORDS}

Social media, Festival, tourism, Festival tourism, eWOM

\section{INTRODUCTION}

In this digital era, the growth of the internet has changed the world and with the content that is available online, people can rapidly find all the information they need. This has facilitated global interconnectivity: the advancement of communication technology has encouraged people to change the way they communicate, receive information, and purchase. This development has also had an impact on how business is conducted by creating new opportunities. As such, the tourism industry has been impacted [26].

\section{LiteratURE REVIEW}

\subsection{Festival Tourism}

Tourism, which is one of the fastest growing economic sectors globally, has become a significant component in the lives of many people and is a function of the socio-economic development of society. The result of this growth has been increasing diversification in the industry with destinations competing for market share[34]. In line with the growth in tourist numbers has been tourists' high 
International Journal of Computer Science \& Information Technology (IJCSIT) Vol 12, No 3, June 2020

expectations and demands for unique experiences. It is necessary to highlight the role of events, especially festival tourism.

Lyck et al.[20], who studied festivals from both generic and specific perspectives, defined a festival as: "An organized set of special events with a specific cultural theme on a specific day or period, normally at a specific place, gathering people in mutual and direct contact to participate in the festival theme."

Falassi[11], who has studied festivals, offered a definition and monograph. He maintains that a festival is an event; it is a social phenomenon that is encountered in virtually all human cultures. He further maintains that it is an organized, unique activity, usually held at a specific geographic location where particular economic activity is conducted. Festival tourism, then, refers to travelling for a festival experience[25].

Festivals are not only a crucial part of tourism but also an integral part of human society. they not only bring tourists to an area and therefore increase revenue but they also promote the development of local industries. At the same time, an awareness of the culture and heritage is stimulated and among residents, cohesion and a sense of their local identity is encouraged.

Festivals are used to create uniqueness and help an area stand out from competitors. This uniqueness will create a demand and either motivate visitors to visit a destination or offer them an alternative that can reinforce their primary objective to travel to a particular destination[24]. Goldner and Ritchie[13] suggest that festivals and events can serve as a powerful tool to attract tourists during the off-season and to create an impression and awareness of an area. They are an excellent means to show off the natural, cultural and historical features of an area as well as the lifestyle of local people. Cudny[7] has studied the positive and negative impacts of festival tourism: because festivals reflect the local culture, they can attract tourists to visit cultural heritage sites, offer them an opportunity to spend their free time in interesting activities and form new relationships. In so doing, they will be supporting local cultural activity and promoting cultural institutions. On the negative side, tourists' activities can increase environmental pollution and cause some conflict with the local people.

Humans never run out of reasons to celebrate and all over the world, festivals give people a platform for sharing with friends and strangers. Therefore, festivals offer a unique opportunity to market a specific destination and offer tourists a satisfying experience. Added to this are the business opportunities available which can increase the income of local people by promoting their unique culture and heritage: local food and beverages, music and dance allow local people and visitors the opportunity to interact socially. A unique, satisfactory experience will encourage tourists to revisit an area and encourage them to recommend the place to others.

Destination image can be defined as the combination of beliefs, ideas and impressions visitors and tourists have of a destination [6][15]. Hanan and Aminudin[14] suggested that destination image can affect visitors' perception of the tourist destination.

While festival tourism can be an important business in attracting visitors to a destination and promoting income, organizers need to develop festival tourism properly. Cudny[7] suggest that festivals, as an essential tourist asset for a given area, should be regarded as a "product" that needs to satisfy the tourists' needs. As a product, the festival can be promoted through marketing tools. 
International Journal of Computer Science \& Information Technology (IJCSIT) Vol 12, No 3, June 2020

\subsubsection{Songkran Festival}

One of the most famous Thai festivals is the Songkran festival [18]. This celebrates the New Year and takes place from 13 to 15 of April every year and has captured the imagination of visitors for both its cultural value and its fun attributes. Thai people welcome in the New Year by splashing with water, symbolically washing away the misfortunes from the past year and also bringing visitors happiness and joy during their travels[3].The appreciation of family is an important aspect of the festival, with many Thai people making their way to their hometowns to spend time with older relatives[28]. Buddhists visit temples during Songkran where they pour water onto statues of Buddha and over the hands of Buddhist monks as a mark of respect.

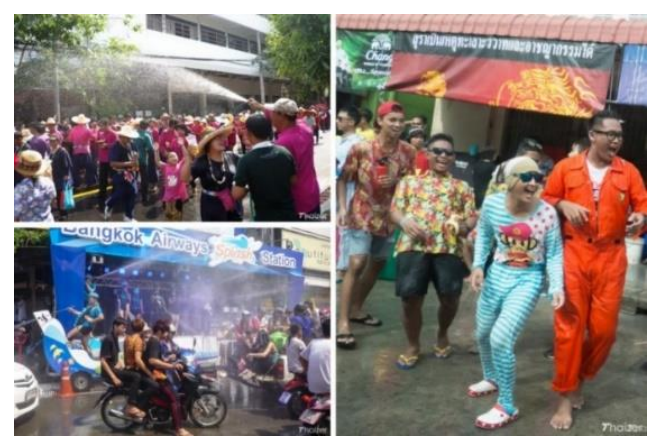

Figure 1 Images of Songkran Festival Source: Cavanagh[3]

\subsubsection{Loi Kratong (the Light Festival)}

The Light Festival, or Loi Kratong, is one of the most beautiful festivals in Thailand and is celebrated throughout the country[33]. It takes place on the evening of the full moon of the 12th month in the traditional Thai lunar calendar (in November). In Chiangmai (Northern Thailand) the Light Festival combines with Yi Peng, a lantern festival and the two are celebrated together. The largest city in northern Thailand, Chai Mai, is known for its flying lanterns rather than its floating offerings. People who visit Chiang Mai during the few days of the festival can also enjoy some of the city's most incredible parades, firework displays, and traditional art performances in public places[35].

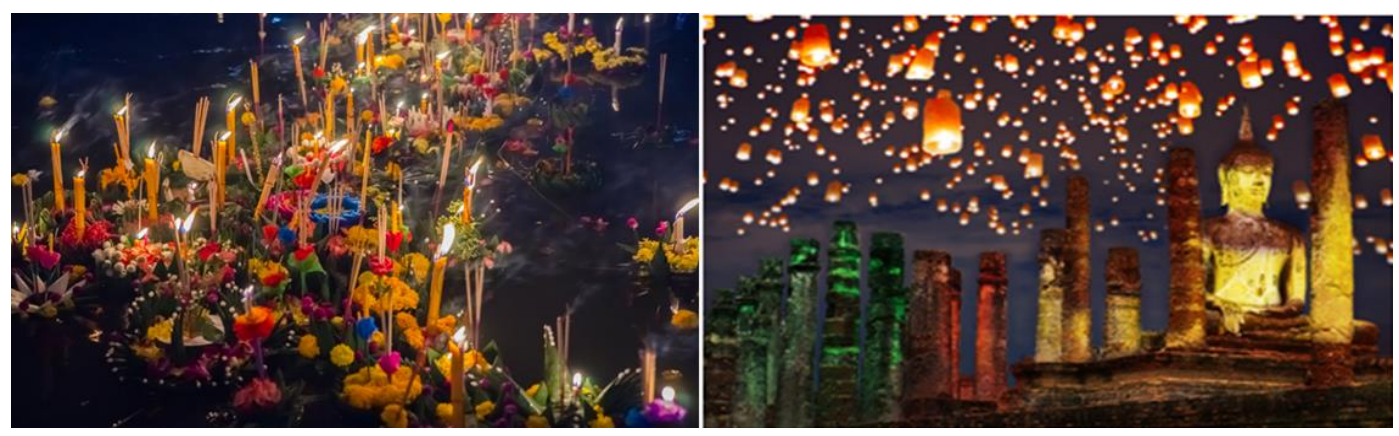

Figure 2 Images of the massive lantern on Yi Peng and Loi Krathong in Chiangmai Source: $\mathrm{Yu}$ [35] 
International Journal of Computer Science \& Information Technology (IJCSIT) Vol 12, No 3, June 2020

\subsubsection{Phi Ta Khon Festival}

The Phi Ta Khon festival is an annual festival that is celebrated sometime between the sixth and seventh lunar month and takes place at the Dan Sai district in Loei Province (in the North-eastern region). This festival is a part of a grand merit-making celebration known as the "Boon Luang" or "Bun Pha Ves" and reflects the local Isan belief in ghosts and spirits[30]. In this festival, men and boys (and now also girls) wear colorful masks and costumes. The clothing was traditionally made from several colorful fabrics. The parade passes in front of reviewing stands on the main street and ends at Wat Phon Chai.

In the past two decades, evolving technology has moved this world into the digital age. Most people have portable devices such as smart phones and tablets and connect to the internet all the time. This behavior impacts the tourism industry, particular festivals and events. The effective marketing methods are using internet technology like social media to develop festivals.

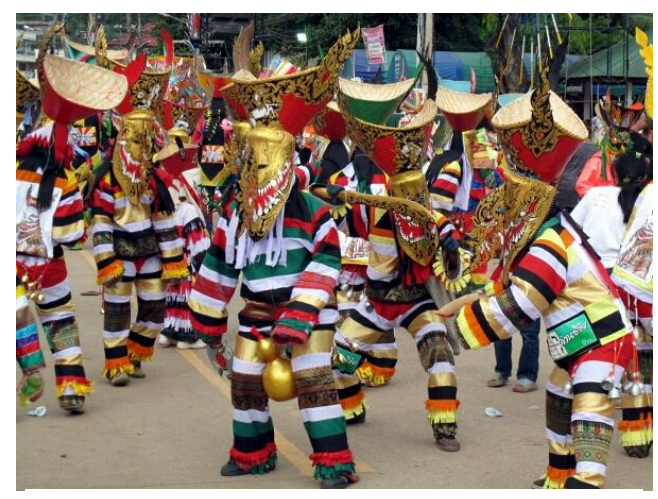

Figure 3 Phi Ta Khon Festival in Lei district Source: Thailandforvisitors[29]

\subsection{Tourism in the Internet Era}

The Internet, with the quantity of information and entertainment available to online users, is growing. Further, social networking is becoming available to more and more people. The content available online offers people rapid access to information and increasing connectedness across the globe.

The Internet has changed the way people communicate and do business. The tourism industry has also been impacted: the internet is the consumer's first choice when searching for information on tourist destinations, and service providers and visitors have more channels through which to interact with companies. Importantly, consumers can now initiate these interactions, which was not possible less than two decades ago.

In the tourism industry, companies try to choose the most effective ways to communicate with customers. There are many options available for visitors to search for information, and interact and share information with others. Companies are embracing social media because of its potential for engagement and collaboration with consumers. Social media advertising will yield relatively stronger results because of its ability to target an audience based on social media activity. 
International Journal of Computer Science \& Information Technology (IJCSIT) Vol 12, No 3, June 2020

Internet technology and the use of mobile phones have dramatically expanded the opportunities for companies to interact with tourists and the internet has become an important tool for the marketing of tourism services[19][27]. Among the available channels, social media is the most reliable and allows content that is wide and varied to be disseminated[39].

\subsection{The Role of Social Media in Festival Tourism}

As social media continues to evolve, the way it is used also continues to change and expand and its definition has changed over time. Therefore, there is no universal definition of social media[27]. Cohen[5] summarized the definitions and identified some essential characteristics of the nature of social media. These include: 1) encompassing a wide variety of content formats including text, video, photographs, audio, PDF and PowerPoint; 2) allowing interactions to cross one or more platforms through social sharing, messaging, email, and feeds; 3) providing for one-to-one, one-tomany, and many-to-many communication; 4) extending engagement by creating real-time online events, extending online interactions offline, or augmenting live events online.

In this era of social media, consumers are seeking experiences that purposely trigger emotional engagement [12][21] Zeng[36] suggested that the role of social media in the field of tourism includes searches for information, making decisions and promoting tourism. Tourism should focus on the best practices for interacting with consumers via social media channels because this provides a collaborative marketing tool by which companies can interact with their customers, receiving feedback and influencing them[9]. The benefits of participating in social media include social capital and feelings of participation[21]. In using social media, visitors feel they are co-marketers, codesigners, co-producers and co-consumers of their travel experiences [26][27]. Therefore, in this study, the role of social media in the tourism industry is construed as a marketing tool for promoting festivals.

\subsection{Social Media Using Behavior}

Social media, one of the most potent online networking tools, has become integrated into social and economic life. Previously, people gathered information from their family and friends, newspapers and televisions. Social media has altered the way people gather news, communicate, shop and make decisions[1].

As mobile technology has developed, it has allowed people to connect to the internet using their mobile devices, thereby increasing the number of social media users and becoming an integral part of the lives of people around the world[31]. Figure 4 shows a number of popular social media's active users, Facebook is the first place with 2,498 million active users. Facebook acquired Instagram in 2012 as an online photo-sharing application. This social network platform, which allows users to edit and upload photos and short videos through a mobile app, has a billion monthly active accounts[14]. Over 95 million photos and videos are shared on Instagram daily [2][23]. YouTube, is the second place, which was developed by former PayPal employees in 2005 and was acquired by Google in 2006, is a popular video-sharing website where registered users can upload and share videos with anyone able to access the site[32].

A different culture has emerged with the increase in social media users. Social connections have become digitalized with people maintaining their social connections through social media, while face-to-face connections are decreasing. It has been established that on average, people use social 
International Journal of Computer Science \& Information Technology (IJCSIT) Vol 12, No 3, June 2020

media for two hours and 16 minutes per day[7]. There are 2.62 billion social media users around the world and this number is expected to grow to over three billion by 2021[31]. This shows that social media platforms have become a powerful social tool for online communication, allowing visitors to interact and share their views, to collaborate and to contribute to developing, extending, rating and commenting on their tourism experiences [26] [27]

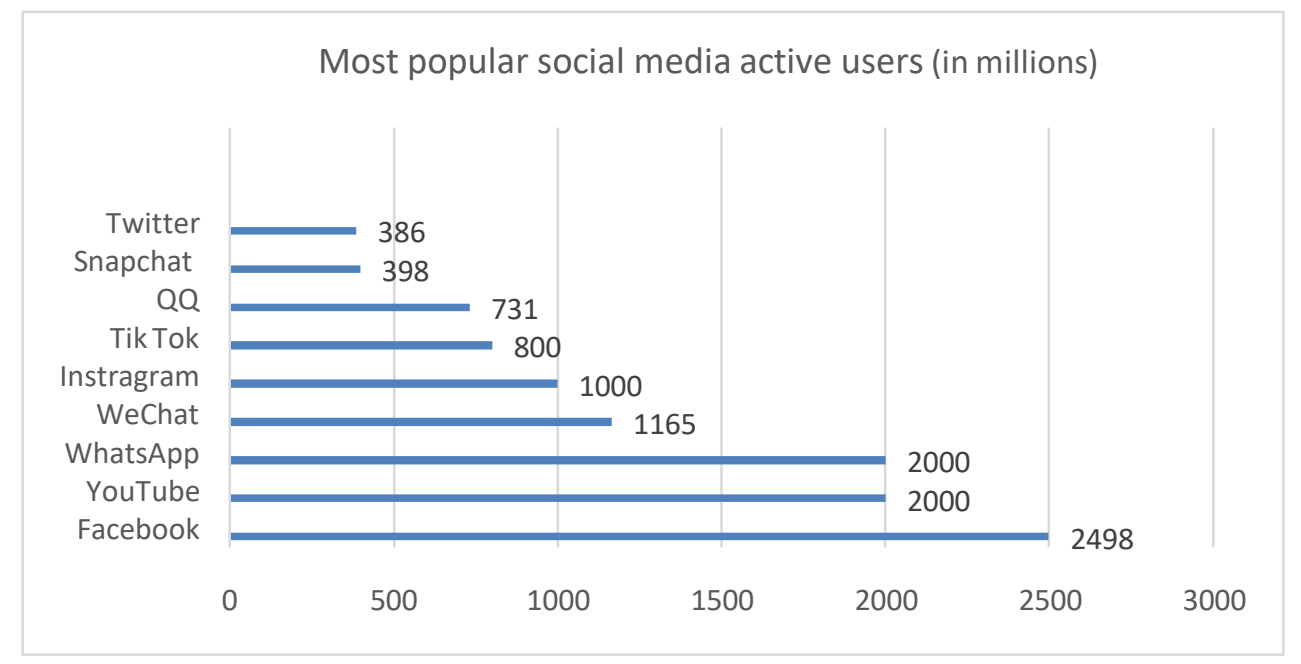

Figure 4: Global users of popular social media platforms Source: Clement [4]

\subsection{Social Media's Influence on Visitors}

Hua et al.[17] note that social media has become a source of information that strongly influences potential customers. In the tourism field, social media plays a significant role in many issues, especially consumer behavior (searching for information and decision-making)[22].

Word of mouth (WOM) refers to the interpersonal communication between consumers about products; now, developments in technology have facilitated online or electronic word of mouth, which can be referred to as eWOM[15][23].

Hua et al.[17] defined eWOM as informal communication concerned with sharing information about products and services with customers on various settings (i.e., social media, traveler's blogs, and online forums). eWOM is also available on portable devices such as tablets and smartphones, making the ability to interact people borderless. Social media can be an authoritative eWOM source, but its impact can be both positive and negative[16][36]. The credibility and quality of the text characteristic of eWOM may be difficult to assess, but can be measured by ratings and number of reviews[23]. Positive eWOM comments and photos on social media of festivals previously visited by tourists can influence levels of motivation; conversely, negative eWOM will de-motivate potential visitors to the festival. The perception of previous visitors will have a direct impact for festival organizers: positive feedback will lead to the creation of a favorable destination image [15], and the directors can use this positive eWOM for advertising [36]. 
International Journal of Computer Science \& Information Technology (IJCSIT) Vol 12, No 3, June 2020

The seminal Engel, Kollatt and Blackwell (EKB) consumer decision-making model [10] (Figure 5) indicates five steps that consumers take when buying a product or service: 1) problem recognition; 2) information search; 3) evaluation of alternatives; 4) purchase; and 5) post-purchase evaluation. Although this model was published more than 50 years ago it is still recognized and is known as the "Five-stage model of the consumer buying process".

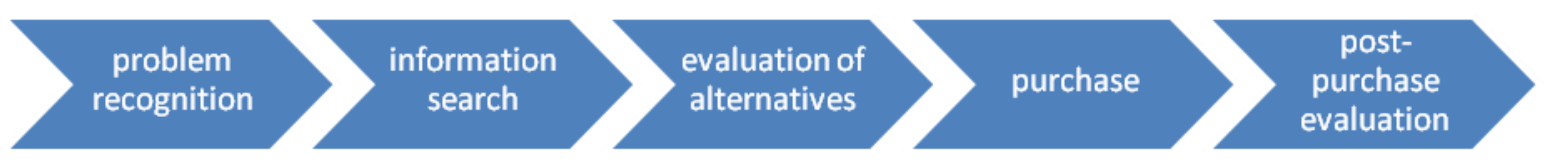

Figure 5 EKB consumer decision-making model

Source: Engel, Kollatt \& Blackwell [10]

Social media has fundamentally changed the tourism industry and has enabled a better understanding of the decision-making process. Applying the EKB model and regarding festivals as a tourism "product" the process can be as follows: the tourists will recognize that they want to join the festival and will start searching for information. People require more and more information about the destination to make sure their needs will be satisfied and they will look for the best options available. People always rely on the first information they receive before comparing this to other information and they tend to come to logical conclusions based on influencing factors, emotional connections, personal experiences or a combination of these factors. When these have been analyzed, they come to a decision about which festival they want to attend. After the trip, they will post information about their experience on social media to encourage or discourage others to travel.

\subsection{Social Media as a Tool for Promoting Festivals}

The successful business should be unique in terms of its value according to customer experience[39]. Festival tourism is shared as a collective experience as part of the festival "product" in terms of investigating social media usage[21].

Tourists need to obtain enough information to make the right decision about travel. According to eWOM, consumers can influence other consumers with their own opinions and experiences. Social media is low-cost, and it represents an advantage for marketing communication. Modern tourists trust other travelers' opinions more than official marketing advice [39].

Even though social media platforms are available 24 hours a day, this does not mean that audiences respond to messages at the same time (Roesler, 2019). De Lira et al. [8] have studied event attendance classified in social media. They classified social media-use behavior into three periods: before, during, and after the festival. Appling the EKB consumer behavior model to social mediauser behavior, using social media as a festival tool, the three periods can be identified as:

1) Before the festival: People generally use social media in their daily lives, connecting with online friends, and posting pictures and videos about their trip. These make people interested and they become motivated about reading more comments on that post. This makes them want to join that festival. Next, they search for more information online about the festival, the costs involved and what they need to know before leaving. When they decide to join that festival, they may explicitly share their intention with the words "Go" or "Packing". They may also chat with their friends and invite them to also go. 
International Journal of Computer Science \& Information Technology (IJCSIT) Vol 12, No 3, June 2020

2) During the festival: They show their actual participation in the event by posting photos, making comments about their experience during the event, or taking live recordings of the event. These activities allow their online friends to share the festival's destination image and the festival environment. Those at the festival also share their feelings and emotions while they are at the festival.

3) After the festival: People often comment, express their opinions or publish memories and photos on social media. This action is an easy way for organizers to access the feedback of visitors and work out how they can improve their service.

Social media is an essential tool for analyzing visitors' attitudes as has been confirmed by the increased purchases and recommendations to other users (i.e., number of likes and shares on Facebook, and retweets on Twitter). Zeithaml, Bitner and Gremler[38] noted that tourists need reliable sources of information about what to expect; this information will reduce feelings of uncertainty and create anticipation of what they are likely to find at their destination. As such, social media is a crucial tool for promoting the festival. The organizers can collect feedback from social media users in these three periods, using the information to add or delete various activities.

\section{METHODOLOGY}

To achieve the above mentioned aims, this study first reviewed related articles published in academic journals and other sources. The role and uses of social media in festival tourism, businesses management and marketing have been widely discussed in academic tourism research. This study reviewed articles published during the past ten years (2009 to 2019) that relate to the use of social media and its effects on tourism and tourism-related industries.

Beginning with the period from May to August 2019, the researcher applied the following keywords: 'eWOM', OR 'social media', OR 'social media using behavior', AND 'festival tourism', OR 'festival image' on the Google Scholar search engine. This search found out a total of 1,170 results. Thus, the eight factors were selected from 52 articles base on the keyword related to the festival tourism.

A similar methodology has been adopted by previous studies that conducted a literature review [19][21][27][37]. It should be noted that only some of the journal articles published in 2019 were reviewed for this study (until the end of August).

The second part is to conduct the structured interviews with social media impact on Festival tourism. The structure interview is classified into two parts. First, ten respondents will be introduced three Thai festival (Song Kran, Loi Kra thong, and Pee Ta Khon) via social media. Later respondents will be interviewed, using social media impact factors from part one to conduct a 10 -set of structure interview questions, to review data gathered from the secondary research, analyzed, and generated social media factors that really impact on festival tourism.

\section{FINDINGS}

This study analyzed factors regarding the impact of social media on festival tourism based on a review of 52 journal articles. During this review, eight key factors were identified. 
Social media networks allow people to connect with the festival and through their posts, express their feelings, experiences, or opinions. From the literature review it can be established that the impact of social media is:

1) It strengthens destination image: social media increases the likelihood of visitors having a good opinion of a festival;

2) Searching for information: social media provides visitors with a better search engine and tourists can read the comments of other users about their experiences and opinions;

3) Advertising: social media enhances cross selling opportunities for festival products and services;

4) Trustworthiness: social media has become a reliable source for tourists. It has the ability to convert consumers from "observers" to "purchasers" because users trust consumer reviews;

5) Consumer loyalty: social media provides visitors brand images. Famous users can increase consumer loyalty;

6) eWOM: social media has become an eWOM channel that affects the consumer decision-making process;

7) Social interaction: social media provides an interaction channel for one-to-one, one-to-many, and many-to-many communication. Both visitors and organizers can respond;

8) Emotional engagement: social media can engage tourists' emotions by instilling ideas that will encourage them to attend the festival.

After conduct the eight social media factor, the second part continues with structure interview.

\section{INTERVIEW DISCUSSION}

Question 1: Do you use social media every day? If yes how frequency you use it?

The first question explores the social media use behavior of respondents to understand their understanding of social media and can answers the following questions.

All the respondents are using social media every day, and familiar to use social media in their daily life. This result shows that all the respondents can understand social media and have ability to answer the following structure interview questions.

\section{Questions 2: From what source did you find festival/event related information?}

This question explores the source of information that respondents use to find festival and event related information. From literature reviews can find out that social media is the most famous source to searching for information. This question is to confirm that social media is really use to find festivals and events information and can be the most famous source of information. 
International Journal of Computer Science \& Information Technology (IJCSIT) Vol 12, No 3, June 2020

The results is most of the respondents $(n=8)$ find festivals and events related information from social media. This results show that social media is the most famous source of information that people use. People can percept many festivals information through "advertisement" on social media. They not only use social media, but they also percept these information from both social media and their friends and relatives $(n=6)$. This results show that they not only find these information by themselves, but also percept these information through their friends and relatives. The "Word of Mouth (WOM)" or the activities that people percept information from their friends and relatives by using social media can be call "electronic Word of Mouth (eWOM)". Thus, some people $(\mathrm{n}=2)$ don't find festival and events information from social media, they only find festivals and events information from their friends and relatives and from travel agency. This result shows that some people still don't trust using social media to find festival information.

\section{Questions 3: Which social media platform you use to respond with other?}

This question is to explore that which social media is the most interesting for respondents and which social media that people use to interact with other the most.

The result show that Facebook and Instagram $(n=5)$ are the most famous social media people finding information and to interact with others:

"I usually use Facebook because it's a mix of many Medias; provide me many kinds of information such as study, work, news, and entertainment. ...I also use it to connect with my family and friends".

Some people prefer YouTube $(n=3)$ because it provide video that make them more understand about festival.

"I usually use YouTube because I can find a lot of information from this platform. It have many videos that really interesting."

Question 4: What is your reaction when you interesting with festival/travel information on social media?

This question is to understand how people respond their feeling through social media and the reason of each activity they respond. The social media activities that people interact with other in this study are 'Like', 'share', 'comment', and 'follow' or 'subscribe'.

All of the respondents $(n=10)$ interact with others by 'Like' their posts. This activity is the simplest way to interact with other.

"I always Like other people photos and videos. It's already my habit, nothing special."

But some people not only respond with others, they also know that if they respond with something the social media algorithm will provide them much more information.

"I always Like that post and sometime follow that page. Because I can know more this kind of information, doing like this can make Facebook algorithm recognized you and provide much more similar of same kind of information." 
International Journal of Computer Science \& Information Technology (IJCSIT) Vol 12, No 3, June 2020

"I just press "Like" it. Because I can find out more information that related that post and just want to interact with others."

They also 'share' that post if it is interesting and want to read it again or want to share it with their friends or let their friend go with them. This activity is advertising by other users. And some respondents also 'comment' the post they think it interesting and want to know more detail about it.

Question 5: What do you think after review these 3 Thai festivals on social media?

This question is to explore how people respond by using social media (Youtube) introduce three Thai festivals (Song Kran, Loi Krathong, and Phi Takhon). These 3 festivals are different and have their own special activities.

Every respondent can understand each festival special characteristics and activities. Most of them can decide to join some of festivals. Social media can engage visitors' emotion and make them decide to join festival.

"Using Youtube make these festival feel interesting. For Song Kran, I'm not really interesting because I feel embarrass when I get wet, this festival look too crazy. For Loi Krathong, I totally interested, because the scene is so beautiful and this festival is meaningful. And for Phi Takhon, I'm a bit interesting because it new for me. I never see this kind of festival before. I really like the mask they wearing and the way they dance. If I have chance I want to participate Loi Krathong and Phi Takhon festival."

"I think Songkran is very interesting, it is funny festival and I want to play water there. The Light festival is almost the same in Taiwan; it is very beautiful and has a good meaning. And the last, Phi Takhon is so cool. I can see many people wear costume and beautiful mask, dancing around the road. If I go to Thailand, I will go there."

Question 6: What do you think about festival information and advertisement on Social media?

This question is to explore the effective of festival information and advertisement on social media. It can check how people think about festival information and advertisement on social media.

The result shows that people prefer to use social media searching for information and think that festival advertisements are interesting and engage their emotion or make them fell want to join the festival.

"I most prefer information that has photo or video than only text. Because photo and video can attract me and let me want to attend the festival"

Some people also think that social media information and advertisement are reliable and make them understand the festival.

"Social media have much kind of information, photo, video, and text from various sources. You can look at comments, and reviewed to double check it the same. It gives me more knowledge to understand that place and to be more familiar with festival before go there." 
International Journal of Computer Science \& Information Technology (IJCSIT) Vol 12, No 3, June 2020

Question 7: For 'official website' and 'other user post' which one you think their information make you feel more interesting?

This question is to compare the effective of social media and website platform in the festival tourism. 'Official website' represent an online travel agency or festival webpage, 'other user post' represent information on social media that post by other users (users generate content: UGC).

Most of respondent $(n=8)$ agree that 'other user post' is more interesting than 'official website'. Some respondents said that other user post on social media can trigged other people emotion and motivate them to go festival.

"I think other user post is importance and affects someone's thoughts. For example, in my case, I travel in Mongolia and upload some photos on social media, my friend would prefer watch my post than official website. It's easily making them want to go travel, it's motivated them."

Some respondents said that the information on other post is more reliable than official website because they think that official website only tell good facts for advertisement. But for 'other user post' write by their experience, include recommends and complains.

"I prefer other user's post and review. Because official website must have their strategy to strengthen their images but other user review often review festival or event base on reality."

A respondent $(\mathrm{n}=1)$ think that both 'official website' and 'other user post' are importance. He said that some details not provide on other user post, but on official website, need to check both of them to understand the festival.

"I think both of them. Because official website can give you more complete accurate and information about what time they start, what time they close, their phone number. But official website only show the good things but other user reviews make you know that information true or not, someone complain or not."

In contrast, one respondent $(\mathrm{n}=1)$ think that 'official website' are more interesting. She said that official website always provide complete information of the festival.

"I think official website can give more complete information about the festival and help me know more culture in that country. Sometimes other user post is seemed to be more interesting, but It don't have enough information."

Question 8: During and after your trip/festival, do you post or share your experience on social media?

This question is to explore people social media using behavior during and after the festival. The social media using behavior can represent the purpose of their behavior.

Most respondent $(\mathrm{n}=9)$ post their photos or videos on social media during and after the festival. They said that they need to share their experience to their friends and relatives, keep their joy and happiness of the festival in their memories. 
International Journal of Computer Science \& Information Technology (IJCSIT) Vol 12, No 3, June 2020

"Sure, during my trip I always take photos or videos and post my IG story. After comeback, I usually upload my photo on IG to keep my memory and to share my experience to my friend. I also reply their comment about my trip."

"Of course, yes. It's a good experience to attend the festival and I want to keep my special memory, I need to post them on social media."

But, one respondent $(\mathrm{n}=1)$ do not want to use social media during and after the festival. He said that social media is a public area, he don't want to provide his information on social media.

"No, I don't like to do it on social media. Because I think that social media is an public space and I don't want other see my self-information. But I must take many photos and videos and keep it in my device."

This question can confirm that "strengthen destination image", "emotion engagement", and "Advertising" factors are impact on festival tourism.

Question 9: Do you think social media can help you planning your festival trip?

This question is to explore the effective of social media on festival tourism. The researcher can understand respondents' opinion on social media for planning trip.

All respondents agree that social media can help them planning their festival trip. Some respondents said that social media is costless and fast way for planning the trip, the information on social media is reliable and can inspire them to attend the festival.

"Yes, it can. I always find many posts that inspired me to go travel and add it to my plan."

Question 10: In overall, do you think social media can help festival tourism?

This question is to confirm that social media can play a good role on festival tourism or not. The researcher needs to understand the benefit of social media on festival tourism in the respondents' opinion.

All respondents $(n=10)$ agree that social media can help festival tourism. They said that social media is really good platform for advertising and searching for information, the information on social media is reliable and can engage their emotion and make them decide to attend the festival.

"Yes, it can. First, social media provide many kind of information that it make me idea to travel. I also can use it searching for information, and then I can know what I should to do during the festival. I also share my experience with my friend and keep my memories."

After analyze the entire interviews, the eight social media factors can organize in three groups through their relation:

1.) Gathering information: advertising, searching for information, and eWOM;

2.) Decision- making: social interaction, and emotion engagement; 
International Journal of Computer Science \& Information Technology (IJCSIT) Vol 12, No 3, June 2020

3.) Tourism evaluation: strengthen destination image, trustworthiness, and consumer loyalty.

\section{Conclusions}

This study aimed to analyze the impact of social media on festival tourism. Social media networks allow people to connect with the festival and people can express their feelings, experiences or opinions on their posts.

Social media was identified as an important tool that festival organizers can apply in the future:

1. As an information search tool, social media is an accessible channel that people use to find information and to communicate with others;

2. As a decision-making tool, social media offers a powerful eWOM that influences people's decision-making behaviors; and

3. As tourism promotion tool, social media is one of the most potent advertising methods. It is not only organizers but also other social media users who review destination images and their own experiences.

\section{REFERENCES}

[1] Al-Ghaith, W. (2015). Applying the Technology Acceptance Model to Understand Social Networking Sites (SNS) Usage: Impact of Perceived Social Capital. International Journal Of Computer Science And Information Technology, 7(4), 105-117. doi: 10.5121/ijcsit.2015.7409

[2] Chaffey, D. (2019). Global social media research summary 2019. Posted by Dave Chaffey on February 12, 2019, in Social media strategy, Digital marketing statistics, Retrieved 9 May 2019, from https://www.smartinsights.com/social-media-marketing/social-media-strategy/new-global-social-mediaresearch/

[3] Cavanagh, R. (2007). Songkran: Thai New Year Water Festival. Retrieved 18 July 2019, from https://www.thaizer.com/festivals/songkran-thai-new-year-water-festival/

[4] Clement, J. (2020). Global social networks ranked by number of users 2020. Retrieved 13 May 2020, from https://www.statista.com/statistics/272014/global-social-networks-ranked-by-number-of-users/

[5] Cohen, H. (2019). Social Media Definition: The Ultimate Guide That Will Make You Smarter. Posted by Heidi Cohen on March 19, 2019, in Marketing Resources, Social Media, (Retrieved 9 May 2019, from http://heidicohen.com/social-media-definition/

[6] Crompton, J. L. (1979). Motivations for pleasure vacation. Annals of Tourism Research, 6(4), 408-424.

[7] Cudny, W., Gosik, B., Rouba, R. (2011). Festiwal kultury chrześcijańskiej w Lodzijako przykład produktu turystycznego - wydarzenie. Ekonomiczne Problemy Usług, 66(648), 89-100.

[8] De Lira, V. M., Macdonald, C., Ounis, I., Perego, R., Renso, C., \& Times, V. C. (2019). Event attendance classification in social media. Information Processing \& Management, 56(3), 687-703. doi:10.1016/j.ipm.2018.11.001

[9] Ellison, N .B., Charles, S .and Lampe, C) .2007(, "The benefits of Facebook "Friends :"social capital and college students 'use of online social network sites", Journal of Computer-Mediated Communications, Vol .12 No .4, pp .1143-1168.

[10] Engel, J.F., Kollat, D.T., \& Blackwell, R.D. (1968). Consumer Behaviour. New York: Rinehart \& Winston.

[11] Falassi, A. (1987) Festival: Definition and morphology. In: Falassi, A., Ed., Time out of Time, University of New Mexico Press, Albuquerque 
International Journal of Computer Science \& Information Technology (IJCSIT) Vol 12, No 3, June 2020

[12] Flinn, J. and Frew, M. (2013), "Glastonbury: managing the mystification of festivity", Leisure Studies, Vol. 33 No. 4, pp. 418-433.

[13] Goeldner, C., \& Ritchie, J. (2012). Tourism (12th ed., p. 188). Hoboken, N.J.: John Wiley \& Sons.

[14] Hanan, H., \& Aminuddin, N. (2012) 'Food festival towards destination image of Kelantan'. In Proceedings of Melaka International Heritage Conferences 2012 \& 5 Tourism Outlook Conference 2012, Shah Alam: Penerbit UiTM: 88-93.

[15] Hanan, H., \& Karim, Ab. S., (2015) "Influence of Social Media in Food Festival Destination Image", International Conference on Tourism and Ethnicity in ASEAN and Beyond 2015

[16] Hede, A. -M., \& Kellett, P. (2012). Building online brand communities: Exploring the benefits, challenges and risks in the Australian event sector. Journal of Vacation Marketing, 18(3), 239-250.

[17] Hua, L. Y., Ramayah, T., Ping, T. A., \& Jacky, C. J.-H. (2017). Social Media as a Tool to Help Select Tourism Destinations: The Case of Malaysia. Information Systems Management, 34(3), 265-279. doi: $10.1080 / 10580530.2017 .1330004$

[18] K5. (2019). 8 things you should do in Thailand - Keyframe5. Retrieved from https://www.keyframe5.com/things-you-should-do-in-thailand/ Accessed on 16 July 2019

[19] Law, R., Buhalis, D., \& Cobanoglu, C. (2014). Progress on information and communication technologies in hospitality and tourism. International Journal of Contemporary Hospitality Management, 26(5), $727-$ 750. doi:10.1108/ijchm-08-2013-0367

[20] Lyck, L., Long, P., \& Grige, A. (2012). Tourism, festivals and cultural events in times of crisis. Copenhagen: Business School.

[21] MacKay, K., Barbe, D., Van Winkle, C. M., \& Halpenny, E. (2017). Social media activity in a festival context: temporal and content analysis. International Journal of Contemporary Hospitality Management, 29(2), 669-689. doi:10.1108/ijchm-10-2015-0618

[22] Marios, D. Sotiriadis, (2017), "Sharing tourism experiences in social media A literature review and a set of suggested business strategies ", International Journal of Contemporary Hospitality Management, Vol. 29 Iss 1 pp. 179 - 225

[23] Nieto, J., Hernandez-Maestro, R. M., \& Munoz-Gallego, P. A. (2014) 'Marketing decisions, customer reviews, and business performance: the use of Top rural website by Spanish rural lodging establishments. Tourism Management, 45, 115-123Oklobdžija, S. (2015). The role and importance of social media in promoting music festivals. Paper presented at Synthesis 2015 - International Scientific Conference of IT and Business-Related Research. doi:10.15308/Synthesis-2015-583-587

[24] ÖZDEMIR, G., \& ÇULHA, O. ( .(2009Satisfaction and Loyalty of Festival Visitors. Anatolia, (2)20, .373-359doi: 13032917.2009.10518914/10.1080

[25] Saiko-Gamble, S. (2011) Global Travel \& Tourism Partnership International Conference Canadian Academy of Travel and Tourism. Elie, Manitoba, Canada

[26] Sigala, M., Christou, E., and Gretzel, U. (Eds) (2012), Social Media in Travel, Tourism and Hospitality:Theory, Practice and Cases, Ashgate, London.

[27] Sotiriadis, M. D. (2017). Sharing tourism experiences in social media. International Journal of Contemporary Hospitality Management, 29(1), 179-225. doi:10.1108/ijchm-05-2016-0300

[28] Shedrick, J. (2019). Songkran Festival: Everything You Need To Know - Hostelworld. Retrieved 16 July 2019, from https://www.hostelworld.com/blog/songkran-everything-you-need-to-know/

[29] Thailandforvisitors. (2019). Phi Ta Khon Festival. Retrieved 18 July 2019, from http://thailandforvisitors.com/isan/loei/dan-sai/phi-ta-khon.php

[30] Thaipaipan Co. (2019). Phi Ta Khon : Thailand's Halloween. Retrieved 18 July 2019, from http://www.thaipaipan.com/index.php?option=com_content\&view=article\&id=1181\&catid=306\&Itemid $=64$

[31] Terrell, K. (2019). The History of Social Media: Social Networking Evolution!. Accessed on 26 May 2019. Retrieved from https://historycooperative.org/the-history-of-social-media/

[32] Techopedia. (2019) What is YouTube? - Definition from Techopedia. Accessed on 22 June 2019 Retrieved from https://www.techopedia.com/definition/5219/youtube

[33] Tourism Authority of Thailand. (2019). Events \& Festivals. Retrieved from https://na.tourismthailand.org/Events-and-Festivals Accessed on 16 July 2019 
International Journal of Computer Science \& Information Technology (IJCSIT) Vol 12, No 3, June 2020

[34] World Tourism Organization and Global Tourism Economy Research Centre (2018), UNWTO/GTERC Asia Tourism Trends - 2018 Edition, Executive Summary, UNWTO, Madrid

[35] Yu, C. (2019). Southeast Asia \& Vietnam Travel Agents - Indochina Odyssey Tours Team. Retrieved 18 July 2019, from https://www.indochinaodysseytours.com/about-iot/team.html

[36] Zeng, B. (2013). Social Media in Tourism. Journal of Tourism \& Hospitality, 02(02). doi:10.4172/2167$0269.1000 \mathrm{e} 125$

[37] Zeng, B., \& Gerritsen, R. (2014). What do we know about social media in tourism? A review. Tourism Management Perspectives, 10, 27-36.

[38] Zeithaml, V., Bitner, M., \& Gremler, D. (2017). Services marketing: Integrating Customer Focus Across the Firm (7th ed.). New Delhi: McGraw-Hill Education.

[39] Živković, R., Gajić, J., Brdar, I. (2014). The Impact of Social Media on Tourism. Paper presented at Sinteza 2014 - Impact of the Internet on Business Activities in Serbia and Worldwide. doi:10.15308/sinteza-2014-758-761

\section{AUTHOR}

\section{Author: Krittanai Ngernyuang}

Mr. Krittanai Ngernyuang is a graduate student of the Tourism and Leisure department at Chung Hua University, Taiwan. He has two bachelor degrees, 1. Bachelor of Police Sciences from Royal Thai Police Academy, Thailand; and 2. Bachelor of Laws from Sukhothai Thammathirat Open University, Thailand.

\section{Corresponding author: Pei-Ying Wu}

Dr. Pei-Ying Wu is an Assistant Professor of Department of Tourism and MICE Management at Chung Hua University, Taiwan. She has an Ph.D. in Events Management from the Leeds Beckett University in England, UK. She is also a qualified NCDA (National Career Development Association) consultant. Her research interests include marketing in events management, Service Quality Management in business events, events impacts measurement, Hospitality and Tourism Management, career development. 